\title{
Confession as a Form of Knowledge-Power in the Problem of Sexuality
}

\author{
liris Kestilä ${ }^{1}$ (D)
}

Accepted: 12 February 2021

(c) The Author(s) 2021, corrected publication 2021

\begin{abstract}
This article addresses two questions related to the discrimination of homosexuals in the British Armed Forces as illuminated in the judgments of the European Court of Human Rights in the cases Smith and Grady v. the United Kingdom and Beck, Copp and Bazeley v. the United Kingdom. First, how does the military organization obtain knowledge about its subjects? Two works by Michel Foucault concerning the thematic of confession-The Will to Knowledge and About the Beginning of the Hermeneutics of the Self: Two Lectures at Dartmouth-provide a foundation for answering this question. Second, what happens when this knowledge obtained by the military organization comes into contact with the legal system? In relation to this question, Foucauldian theories of law are discussed, namely the so-called 'expulsion thesis' and 'polyvalence theory'. It is argued that the production of knowledge in the context of these cases is intertwined with the technique of confession. However, the confession does not only operate at the level of the military organization but also as an internal practice of the individual. When this knowledge then encounters the legal system, it appears that the law puts up a certain resistance towards other forms of power, e.g. disciplinary power. It is argued that this resistance is due to the law's 'strategic openness', i.e. the possibility to harness the law to different strategic purposes, due to which law can never be fully subordinated by external powers.
\end{abstract}

Keywords Confession - European Court of Human Rights · Expulsion thesis · Homosexuality $\cdot$ Knowledge-based power $\cdot$ Michel Foucault $\cdot$ Polyvalence

Iiris Kestilä

iiris.kestila@ulapland.fi

1 Faculty of Law, University of Lapland, Rovaniemi, Finland 


\section{Introduction}

It seems that nobody in Alexina's feminine milieu consented to play [...] the difficult game of truth which the doctors later imposed on his indeterminate anatomy, until a discovery that everybody delayed for as long as possible was finally precipitated by two men, a priest and a doctor. (Foucault 1980, p. xii)

The above quotation by Michel Foucault is a passage from the memoirs of Herculine Barbin, known as Alexina by her/his familiars but subsequently renamed as Abel Barbin. Alexina, who had lived as a female, was later on recognized to be 'truly' a young man (Foucault 1980), and was officially reclassified as male. S/ he lived in France in the mid-nineteenth century, and went to a Catholic school. $\mathrm{S} /$ he later worked as a teacher in a nearby town, and became the lover of a fellow schoolmistress. Later Alexina confided in a priest about her ambivalence, and was sent to a medical examination. Due to certain anatomic features, s/he was 'discovered' to 'belong' to the male sex and was obliged to make the legal change of sex after judicial proceedings (ibid.). Alexina's life was not a happy one and neither was the way it ended: s/he eventually committed suicide at a young age. I will not further discuss Alexina's case here, but the life s/he lived and the quotation by Foucault serve to illustrate some of the central themes of this paper.

Moving to more recent times, let us take a couple of more examples. In 2017 the European Court of Human Rights (later on 'the Court') ruled on the case AP, Garcon and Nicot $v$. France which concerned the possibility for transgender persons to change their gender marker on official documents as well as their forenames on their birth certificates to match their gender identity. The applicants complained that the fact that they had to substantiate this request by proving that they actually suffered from a gender identity disorder, and that the change in their appearance was irreversible, amounted to a violation of Article 8 of the European Convention on Human Rights (later on 'the Convention') - the right to private and family life (AP, Garcon and Nicot, para 3). We might thus say that the essential question in the case came down to whether the applicants were truly transgender. Then, in 2018, the Court of Justice of the European Union dealt with the case of $F$ v. Bevándorlási és Állampolgársági Hivatal, where the Hungarian migration officials had aimed to substantiate an asylum seeker's claim of being homosexual by psychological tests. Somewhat similarly to the case of AP, Garcon and Nicot, the issue was whether the applicant was truly homosexual.

It would seem that there is something fundamentally problematic about the truth in relation to these matters, let us say gender and sexuality. In The Will to Knowledge, part one of The History of Sexuality, Foucault introduces the idea that the Western society has, for some time now, been obsessed by the need to know the truth about sexuality. Foucault questions sexuality as repressed and, instead, notes that, if anything, discourse on sexuality has exploded. In order to unearth the truth about sex, extensive technologies have been developed around the subject. Building on Foucault's work, my interest is not in the problematic of gender 
and sexuality in a strictly juridical sense, although my laboratory in this article consists of cases from the Court and especially the application of Article 8 of the Convention. Rather, my focus will be on the ways in which these technologies of knowledge-based power come to light in legal cases and what happens when the knowledge generated by this power comes into contact with law.

My aim is to explore the techniques of knowledge-based power in the context of the military organization. The paper addresses two questions in this context. What kind of techniques to produce knowledge about individuals can be detected in the context of military? To answer this question, I will look at the facts of the cases and read them against certain texts by Foucault that deal with the thematic of confession. What happens when this obtained knowledge encounters the legal system? To answer this question, I will move from the facts to the reasoning and the judgment of the Court. It has sometimes been argued that Foucault did not think too much of the legal system but rather ignored it or saw it as subordinate to other societal powers. However, are there other ways to see the role of law?

Returning to the opening quotation, two characters come to mind: a priest and a doctor. Still building on a Foucauldian framework, these two characters appear to intertwine with a certain practice of knowledge-production-confession. An individual is invited to confess every little detail about their sexuality in the vein of Christian tradition and yet this information does not constitute truth without an outside interpreter, the doctor who can decipher the peculiar symptoms of the patient (Foucault 1976, pp. 66-67).

To my understanding, these mechanisms of knowledge-production are particularly well illuminated in the line of cases from the Court concerning discrimination of homosexuals in the British Armed Forces. Out of the total of four such cases, two will be examined here in detail: Smith and Grady v. The United Kingdom and Beck, Copp and Bazeley v. The United Kingdom, from the years 1999 and 2002, respectively. The key issue in these cases was the application of the guidelines drafted by the British Ministry of Defence, banning homosexuals from serving in the army. Because homosexuality was a ground for discharge from the Armed Forces, whenever such suspicions arose, it was considered necessary to substantiate the truthfulness of the claims. In both cases examined here, the applicants considered that the investigation into their sexuality violated their rights under Article 8 of the Convention.

The article is constructed as follows. I will first introduce the thematic of confession more generally. Then I will discuss certain ideas by Foucault concerning the thematic of confession by way of explaining the facts of the two cases and how they illustrate the points made by Foucault. The purpose of this exercise is to learn about the ways in which confession operates in this context and thus the ways in which the military organization produces knowledge about its subjects. After this, I will then analyse the two judgments of the Court to reveal what happens when this knowledge obtained by the military organization comes into contact with the legal system. Whilst doing this, I will utilise the Foucauldian concept of polyvalence to explain the features that come to light in the context of the cases. The final section concludes the discussion. 


\section{Confession}

Let us start with the thematic of confession. Following Foucault, and bearing the two characters - the priest and the doctor - in mind, we might think that the truth about sexuality is produced, on the one hand, through the practices that derive from the Christian tradition of confession (see e.g. Peters 2003, p. 365; May and Bohman 1997) and, on the other hand through practices that could be referred to as judicialmedical (see e.g. Salter 2007, p. 58). What combines these two branches is the way they make the subject reveal the most intimate details of their sexuality, and yet, this information does not constitute truth without interpretation by an outsider (see e.g. Posel 2008, p. 134; Rose 1999, p. 240). What is needed is a priest to hear the confession of a sinner or a doctor to decipher the peculiar symptoms of a patient. As Foucault notes:

The truth did not reside solely in the subject who, by confessing, would reveal it wholly formed. It was constituted in two stages: present but incomplete, blind to itself, in the one who spoke, it could only reach completion in the one who assimilated and recorded it. (Foucault 1976, p. 66)

The sexuality of a subject is a secret, not only to everyone else, but it is also hidden from the subject themselves. In order to find out the truth about this fundamental secret, technologies of power ${ }^{1}$ have been developed around the subject. For Foucault, the technique of confession, together with the thematic of truth, was central to many of his works (see e.g. Foucault 2000a; Foucault 2005, 2017, 2014a, b). ${ }^{2}$ This article largely relies on two texts dealing with the concept of confession: The Will to Knowledge and About the Beginning of the Hermeneutics of the Self: Two lectures at Dartmouth.

The theme of confession was outlined as clearly important in the will to knowledge, although Foucault later on changed his course to some extent (Elden 2005 pp. 24-26). In The Will to Knowledge, as mentioned above, he questions the so-called 'repression hypothesis': the idea that sexuality is somehow repressed as presented e.g. by Sigmund Freud (Foucault 1976, p. 10; Freud 1952[1910]). Instead, we speak about sexuality like never before and, indeed, must confess everything and anything related to it. In this way, verbalization of sexuality becomes intrinsically intertwined with the practices of power, but not in the negative sense, via restrictions. Instead, Foucault rather wishes to discuss the proliferating effects of power, those effects that generate behaviour. These practices of power then lead to the situation where

\footnotetext{
1 The reader might wonder what the difference between the terms 'technique' and 'technology' is. Although Foucault often used these terms interchangeably, Behrent argues that there was also a difference between them (2013, pp. 58-59). In this article, I use the term 'technique' to refer to certain kind of methods and 'technology' to refer to power relations and the ways they operate.

${ }^{2}$ However, the thematic of confession is to some extent visible also in Foucault's writings about Antiquity, such as History of Sexuality Vol.2: The Use of Pleasure (1985). See also Taylor: in Ancient Greece, individuals would also examine one's actions, however, less to tell the truth and rather to direct oneself towards the philosophical idea of the good life (2009, pp. 13-14).
} 
individuals will subjugate themselves to power via self-monitoring and reporting those observations about themselves.

As noted by David Tell (2010, p. 97), The Will to Knowledge often constitutes the reference point for research concerning Foucault's ideas on confession. The concept of confession, as outlined in The Will to Knowledge, has been discussed e.g. from the point of view of media studies (Mandziuk 2001), Catholic confessional practices (May and Bohman 1997), operation of Truth and Reconciliation Commissions (Posel 2008) and social media (Matabane 2017), to mention a few. However, the thematic of confession is discussed more thoroughly in Foucault's lectures entitled About the Beginning of the Hermeneutics of the Self, delivered at the Dartmouth College on 17 and 24 November in $1980 .{ }^{3}$ The lectures consist of two parts entitled 'Subjectivity and Truth' and 'Christianity and Confession'. These lectures address the thematic of confession and especially its interpretative function. One of the main arguments of these lectures is that while individuals start extensively monitoring their own thoughts and behaviour as presented in The Will to Knowledge, this activity simultaneously requires interpretation and deciphering of those thoughts to find out their origin and especially whether they are good or bad, so to say (see e.g. May and Bohman 1997, p. 139). ${ }^{4}$ Foucault traces the ways in which speaking the truth functions as 'a technique of power', which then produces the subject's relation to the self (Coe 2016).

On the one hand, my interest lies especially in the ways these mechanisms of confession and interpretation operate at the level of the military organization and, on the other hand, at that of the subject. As stated above, although Foucault's ideas of confession have been discussed from numerous perspectives, confession in the context of security has only rarely been addressed, ${ }^{5}$ although we can observe a clear link between confession and the operation of the disciplinary power in Foucault's work. Indeed, according to e.g. Chloë Taylor, the 'techniques of domination and techniques of the self are always interwoven' (2009, p. 9). This connection is also noted by Arnold Davidson in the introductory part of Foucault's Abnormal lectures. As Davidson points out, 'Foucault's work from the early 1970s, his courses, lectures, interviews, and books, provides a wealth of material from which one could begin to write a genealogy of the examination, a genealogy that would intersect with the history of confession' (2003, p. xxiv). The concept of examination, ${ }^{6}$ a normalizing practice of power that operates in schools, hospitals as well as the military, is then

\footnotetext{
${ }^{3}$ In 1980 Foucault gave a series of lectures of which the Dartmouth lectures form a part. He also gave lectures in the University of California at Berkeley, Princeton University and New York University. Foucault had given more or less the same lectures as Howison Lectures in Berkeley on 20 and 21 October (Blasius 1993).

4 Foucault brings up this aspect also in Volume 2 of History of Sexuality: The Use of Pleasure, where he describes technologies of the self as "models proposed for setting up and developing relationships with the self, for self-reflection, self-knowledge, self-examination, for the decipherment of the self by oneself, for the transformations that one seeks to accomplish with oneself as object' (1990, p. 29).

${ }^{5}$ However, this does not mean that the link between security and confession would not have been discussed at all, see e.g. Salter (2007).

${ }^{6}$ In Discipline and Punish Foucault describes examination as a 'mechanism that links a certain type of formation of knowledge to a certain form of exercise of power' (1995, p. 239).
} 
more thoroughly discussed in Discipline and Punish (Foucault 1995). In this regard, Davidson also notes the similarities between the Abnormal lectures and Discipline and Punish (2003, p. xxii).

To illustrate the joint functioning of the mechanisms of confession and interpretation, I will deploy two conceptual pairs, which I have likewise borrowed from the abovementioned texts by Foucault. These concepts are ars erotica and scientia sexualis as presented in Will to Knowledge; and exomologesis and exagoreusis from About the Beginning of the Hermeneutics of the Self. The concepts of ars erotica and scientia sexualis aid me to address the mechanisms of knowledge production that operate at the level of the military organization. The concepts of exomologesis and exagoreusis, then, contribute to the ways in which the subject produces knowledge of themselves, that is, the ways in which these mechanisms of knowledge production become internalized. These mechanisms become visible in the cases of Smith and Grady v. the United Kingdom and Beck, Copp and Bazeley v. the United Kingdom.

\section{Facts of Smith and Grady}

Let us begin by addressing the case of Smith and Grady v. the United Kingdom. The case originated in two applications against the United Kingdom of Great Britain and Northern Ireland and the judgment was delivered in 1999. The applicants, Ms Smith and Mr Grady, both served in the Royal Air Force. In both cases, suspicions had been raised concerning their sexual orientation, i.e. whether the applicants were homosexual. The Royal Air Force therefore launched investigations to find out whether the applicants were indeed homosexual. Once their homosexuality was confirmed in the investigations, the applicants were discharged from the Royal Air Force.

The legal context for these two cases was provided by certain legislative changes in the laws regarding homosexuality as a criminal offence as well as Armed Forces' policy regarding the issue. ${ }^{7}$ According to this new law, homosexuality was no longer a criminal offence but it left the Armed Forces the possibility to classify homosexuality as a reason for discharge. According to the policy, homosexuality was considered incompatible with service in the armed forces. When dealing with cases of suspected homosexuality, a Commanding Officer was to make 'a balanced judgment taking into account all the relevant factors' (Smith and Grady v. the United Kingdom, para 49.) It was recommended that in these cases a formal investigation would be opened (ibid.).

The cases of Ms Smith and Mr Grady originated in these circumstances. In both cases, the Armed Forces' authorities had gained information that suggested that Ms

\footnotetext{
7 In the background of it was also affected by the so-called Wolfenden report (Home Office, Report of the Committee on Homosexual Offences and Prostitution), the purpose of which was to provide information on the criminalization of homosexual acts. Although the report eventually advocated for decriminalization of homosexual acts between consenting adults, it has been argued that it nevertheless established an idea that homosexuality was in essence immoral. See e.g. Johnson (2014, p. 100).
} 
Smith and Mr Grady might be homosexuals, following which investigations were initiated.

In Ms Smith's case, noteworthy is the fact that investigations took place after Ms Smith had already admitted her homosexuality. In its submission, the British Government noted that the investigation took place if homosexuality was denied but also if it was admitted. This was to substantiate the truthfulness of the allegations. The aim of the investigations was to "verify the homosexuality of the person suspected in order to detect those seeking an administrative discharge based on false pretences' (Smith and Grady v. The United Kingdom, para 80).

Therefore, the service police interviewed Ms Smith. The interview lasted approximately thirty-five minutes. She was asked how she came to realise that she was lesbian, the names of her previous partners and numerous times whether her previous partners were in the service. She was questioned about how she had met her current partner and the extent of their relationship. When she refused to respond, the interviewer asked how else he was to substantiate her homosexuality. She then confirmed that she and her partner had a full sexual relationship. She was also asked whether she and her partner had a sexual relationship with their foster daughter who was 16 years old. She was also asked "whether she had thought about HIV, whether she was being "careful", what she did in her spare time and whether she was into "girlie games" like hockey and netball' (Smith and Grady v. The United Kingdom, para 14-15).

In Mr Grady's case, the central themes of the interviews consisted of Mr Grady's marriage difficulties, the sleeping arrangements with his wife and his cycling holiday with a male colleague. Mr Grady denied being homosexual. He was asked numerous questions about his work, his relationship with the head of the unit he worked at, his cycling holidays with a male colleague and about his female colleague. He was asked to tell the interviewers about the break-up of his marriage, whether he had extra-marital affairs, about his and his wife's sex life including their having protected sex and about their financial situation. He was further questioned about the cycling holiday, about a male colleague and the latter's sexual orientation (Smith and Grady v. The United Kingdom, para 25). After the first interview, Mr Grady sought legal advice, after which he refused to answer the questions in the second interview. However, he finally admitted his homosexuality adding that the reason he denied it at first was that he was uncertain about certain accumulated benefits on discharge and that he was therefore concerned about his family's financial situation.

Mr Grady was then further questioned about a person called 'Randy', whether his wife knew he was homosexual, whether a male colleague was homosexual and when he had 'come out'. He was asked whether he was 'a practising homosexual'. After Mr Grady refused to give the name of his current partner, it was then explained to him that his admission of homosexuality would have to be substantiated in order to avoid fraudulent attempts at early discharge. He was then questioned about his first homosexual relationship, his homosexual partners (past and present), who they were, where they worked, how old they were, how he had met them and about the nature of his relationship with them, including the type of sex they had. Lastly, he was also questioned about when he first realized he was homosexual, who knew about his sexual orientation, his relationship with his wife (including their sexual 
relationship), what his wife thought about his homosexuality, his HIV status and again about the nature of his sexual relationships with his homosexual partners (Smith and Grady v. The United Kingdom, para 27.).

\section{Confession and Interpretation}

What does the case discussed above tell us about the practice of confession? Returning to Foucault and The Will to Knowledge, could we say that the ways of producing the truth about sexuality as exemplified by this case are somehow grounded in the act of confession? According to Foucault, historically there have existed two great procedures for producing the truth about sex: ars erotica, on the one hand, and scientia sexualis, on the other (Foucault 1976, pp. 57-58). Perhaps we could say that ars erotica-erotic art-is based on the secret: it is the master of this art who holds the secret and only they can transmit it to the disciple. This kind of knowledge must remain a secret, as 'according to the tradition, it would lose its effectiveness and virtue by being divulged' (Foucault 1976, p. 57).

Foucault then continues that our Western civilization does not possess ars erotica. Instead, our civilization is a certain kind of rarity, the only one which practices scientia sexualis. As Foucault notes, it is:

[...] the only civilization to have developed over the centuries procedures for telling the truth of sex which are geared to a form of knowledge-power strictly opposed to the art of initiations and masterful secret: I have in mind the confession. (Foucault 1976, p. 58)

The foundation for scientia sexualis could be considered to reside in the two characters introduced in the beginning: the priest and the doctor. It is through the institutions these characters represent-the Church and Science-that truth about sex came to be produced via an act of confession that operated through the norms of scientific regularity. The juridico-religious model of confession became intertwined with scientific methods of extorting evidence.

Let us take a closer look at the technique of confession. The confession operates in a way of dual relationship between the one who confesses and the one who hears the confession. This relationship is also one of power as the person who hears the confession 'is not simply an interlocutor but the authority who requires the confession [...]' (Foucault 1976, p. 61). The subject who speaks is also the subject of the statement (ibid.). The one who listens to the confession has the power to judge and punish but also to forgive and console. The one who confesses is, conversely, unburdened of his wrongs, liberated (Foucault 1976, p. 62). And yet, almost nothing could be further from freedom, as the act of confession is obligatory and exhaustive. As Foucault notes, we assume that it is the power that holds sexuality within the domain of silence and represses it. Instead, it is the power that constantly generates the discourse on sexuality and makes us confess every little, secret detail about it. But how to confess that which is a secret?

As discussed before, the thing about sexuality is that it is not only something that the subject wishes to hide but what hides from the subject himself (Foucault 1976, 
p. 66). This leads us to the integration of confession into the scientific discourse, which modifies the scope of confession:

If one had to confess, this was not merely because the person to whom one confessed had the power to forgive, console and direct, but because the work of producing the truth was obliged to pass through this relationship if it was to be scientifically validated. (Foucault 1976, p. 66)

As the subject cannot explicate the truth as wholly constituted, an outsider is needed to interpret what is being said. Truth is construed in a two-stage process: between the one who speaks and the one who deciphers what is being said (ibid.). The one who listens to the confession is not merely a forgiving master but now becomes 'the master of truth with a hermeneutic function' (ibid.). Making sexuality into something that has to be interpreted is precisely the way sexuality was brought to scientific discourse.

Now, in the case that I have discussed here, the elements of confession and extorting evidence via scientific methods appear to be present. The starting point with both applicants was the suspicion of their homosexuality. However, the suspicion persisted despite the applicants' admission of their homosexuality, which was especially visible in the case of Ms Smith where the investigation was launched only after her confession. As the British Government submitted, there was a need to know the truth about her sexuality. Foucault also notes this sort of suspicion towards sexuality, as if there were indeed some fundamental secret that sexuality harbours (Foucault 1976, p. 69). This suspicion causes the emergence of two processes: we demand that sex speaks the truth but also that it speaks us our truth: 'the deeply buried truth of that truth about ourselves which we think we possess in our immediate consciousness' (ibid.) By deciphering what sexuality says about itself we are given back what is our own, yet unknown to us. What Foucault calls a knowledge of the subject is constructed by delivering us this very part that escapes us. That is, not the knowledge of the subject's form but that which divides him, and most of all, that which makes him ignorant of himself (ibid.).

In case of both applicants, this truth was then sought via methods that Foucault would describe as interrogation, the exacting questionnaire and the recollection of memories (Foucault 1976, p. 65). Both applicants were asked detailed questions about the nature of their sexual relationships but also about how they first came to realize that they were homosexual as well as about the development of their sexuality. Noteworthy in the case is also the way sexuality appears to reach every corner of the subject's experience. The questions that the applicants were asked did not relate 'only' to sex but also to their relationships to co-workers, financial status and relationship to their family, especially children. Perhaps this practice reveals something about what Foucault refers to as general and diffuse causality of sexuality (ibid.). Justification for the obligation to tell everything was found from the all-powerful causal power of sex. Confession has to be thorough and constant as sex is a cause of anything and everything (Foucault 1976, pp. 65-66). As Foucault notes:

The confession has spread its effects far and wide. It plays part in justice, medicine, education, family relationships, and love relations [...]. One goes about 
telling, with the greatest precision, whatever is most difficult to tell. (Foucault 1976, p. 59)

But why is all this information about sexuality needed? Who needs it? What Foucault seems to suggest is that not only the one who receives the confession but also the one confessing (Foucault 1976, p. 71). There is a certain pleasure in the act of unearthing our deepest secrets. However, to claim such a thing in the context of the case discussed here would be nothing short of grotesque. Might we instead ask whether this kind of desire is embedded in the system that requires the confession? Is there pleasure in this extensive, multiplying and intense truth-production about sex? Have we, instead of abandoning ars erotica, merely invented new forms of pleasure in finding the truth about pleasure and having those new forms of eroticism integrated into technologies that penetrate our privacy? As Foucault notes, must we conclude that scientia sexualis is rather an extraordinarily subtle form of ars erotica? (ibid.). Perhaps we should, instead of the sexuality of the subject, consider the sexuality of the army, the church, medicine or law.

Next, we will take a look at the feature of difficulty in confessing one's thoughts. Why is it that certain thoughts appear to be more difficult to say out loud and almost resist verbalization? And why is it that, nevertheless, it is precisely the same thoughts that we feel the need to talk about? Whereas in the case of Smith and Grady it appears that the will to confess derived rather from the security system than from the applicants themselves, in the next case, we will take a look at how the technique of confession operates in the inner world of the subject.

\section{Facts of Beck}

The subject's inner urge to confess is illustrated in the case of Beck, Copp and Bazeley v. the United Kingdom and especially in the case of Mr Beck. In 1976, Mr Beck had joined the Royal Air Force. By 1993 he had reached the rank of sergeant and was employed as a communications systems analyst. He had divorced in 1988. His conduct had been evaluated as exemplary and his evaluation was also otherwise very good. By 1993 he had been studying theology and was considering ordination; that is, becoming a priest. In May 1993 he took a course meant to aid participants to assess their suitability for ordination. He claimed that, during the course, he had 'realised that he could no longer deny his homosexuality and that he felt morally bound to reveal his sexual orientation as he was aware of the policy against homosexuals in the armed forces'. On the next day after the course he told the security officer that he was homosexual, although a celibate one. Later that day he also admitted his homosexuality to his superior. Similarly to the case of Smith and Grady v. the United Kingdom, an investigation was opened by the service police (Beck, Copp and Bazeley v. the United Kingdom, para 12-16).

The security officer to whom Mr Beck had spoken after the course described the visit during which Mr Beck had admitted his homosexuality to the service police. He reported on the information that Mr Beck had provided on his family and 'how he had lived his homosexuality in armed forces'. The security officer 
also emphasized the view that Mr Beck was indeed a homosexual and not trying to get an early release from the armed forces. The officer also described $\mathrm{Mr}$ Beck's visit to a medical officer and a referral to a visiting psychiatrist. According to the psychiatrist, Mr Beck did not suffer from a clinical disorder (Beck, Copp and Bazeley $v$. the United Kingdom, para 17).

The other officer who had interviewed Mr Beck after the investigation had been opened also stated that Mr Beck was a genuine homosexual and not attempting to get an early release. Mr Beck's superior described Mr Beck's character and interest in theology, noting that he was not surprised that Mr Beck was homosexual, although his homosexuality had never showed. While he believed Mr Beck, he added that he had never seen or heard anything that would substantiate Mr Beck's story (Beck, Copp and Bazeley v. the United Kingdom, para 18).

Statements were obtained also from two of Mr Beck's colleagues. The first had been a close friend to Mr Beck and knew about his homosexuality already before the armed forces' authorities. This colleague described his relationship to Mr Beck, including his wish to be ordained. Both colleagues interviewed described Mr Beck as a "'man's man" who gave no indication of his homosexuality'. In addition to the statements of the colleagues, the Station Padre's evidence was recorded. Mr Beck's religious studies as well as his aspirations towards priesthood were outlined. According to the Station Padre, Mr Beck was 'a clever individual who would attempt to get what he wanted, the way he wanted'. Mr Beck's ex-wife was also interviewed on their marital difficulties, their financial difficulties, their separation and their divorce (Beck, Copp and Bazeley v. the United Kingdom, para 19-21).

The report finally concluded that:

no signs of homosexual tendencies were identified by the first applicant's ex-wife, colleagues or friends, that the only evidence was the first applicant's own admission and that the enquiry had not revealed anything to rebut the first applicant's submissions that he had not had a homosexual physical relationship. (Beck, Copp and Bazeley v. the United Kingdom, para 22)

The Unit Commander's recommendation for administrative disposal of the matter later on recorded that:

despite the devious and deliberate concealment of his homosexual tendencies, [Mr. Beck's] honesty and character have caused him finally to admit to the truth. [...] [Mr. Beck] has nowhere to live outside the Sergeant's Mess ... As such this lonely and solitary individual, who has had to face up to a situation not of his own making, deserves to be treated in a compassionate and dignified manner. ... [Mr. Beck] has had to cope with extreme personal difficulties which have not previously impacted on the Service. These difficulties, which have been beyond his control, have caused him to become a lonely and solitary man, and finally to admit to his true personality. (Beck, Copp and Bazeley v. the United Kingdom, para 23)

On 10 August 1993, two of the members of a Board of Royal Air Force described Mr Beck's case as 'a murder inquiry without a body' as he had confessed his 
homosexuality 'without any evidence to confirm or deny his claim'. However, on 27 November 1993 Mr Beck was nevertheless discharged from the Royal Air Force on the basis of his homosexuality (Beck, Copp and Bazeley v. the United Kingdom, para 25-26).

\section{Interpretive Analysis of the Self}

As Foucault notes, the examination of conscience and confession are among the most important of the procedures of producing the truth about oneself (Foucault 1993, p. 204). Perhaps the most striking feature of the case of Mr Beck is the way he found himself morally obliged to admit his homosexuality although he knew it would cost him his job. The fact that he came to this conclusion after the course, the purpose of which was to evaluate whether a person was fit to become a priest, is also worth noting. Unlike in the case Smith and Grady, Mr. Beck voluntarily felt the need to confess his homosexuality to the armed forces' authorities. Based on this setting, let us again take a closer look at the act of confession.

Foucault begins his lecture entitled 'Christianity and Confession' by returning to the formation of what he calls the interpretive analysis of the self (Foucault 1993, p. 210). According to Foucault, Christianity in itself is a confession which imposes on those who practice it the obligation of truth (Foucault 1993, p. 211). Examples of this kind of obligation are the obligation to hold true certain propositions that constitute a dogma, hold certain books as a source of truth or accept decisions from authorities in matters of truth (ibid.). And yet, a Christian is subjugated to other kind of obligation as well. According to Foucault:

Everyone, every Christian, has the duty to know who he is, what is happening in him. He has to know the faults he may have committed: he has to know the temptations to which he is exposed. And, moreover, everyone in Christianity is obliged to say these things to other people, to tell these things to other people, and hence, to bear witness against himself. (Foucault 1993, p. 211)

Following Foucault, I will concentrate on the obligation to manifest the truth about oneself (Foucault 1993, p. 212). This manifestation in the Christian institutions of the first centuries takes two forms: exomologesis and exagoreusis. Exomologesis refers to an act related to penance, where, in short, the person doing the penance showed himself as a sinner with somatic and symbolic expressions, such as ash, wretched clothes and fasting (Foucault 1993, pp. 213-214). Foucault refers to Tertullian, according to whom what exomologesis means is publication sui, 'the Christian had to publish himself' (Foucault 1993, p. 214). This publication of the self included two features. First, showing oneself as a sinner, 'as somebody who preferred spiritual death to earthen life' (ibid.). Exomologesis was a kind of representation of death, renunciation of oneself to get access to spiritual life (ibid.). Second, exomologesis was also the model of martyrdom: 'The martyr is he who prefers to face death rather than to abandon his faith' (Foucault 1993, p. 215).

Exagoreusis is quite different from exomologesis. It is rooted in verbal confession whereas exomologesis, as described, rather relates to the public, and bodily, 
manifestation of the truth. The deeper roots of exagoreusis go into self-examination practiced in the monastery. This self-examination was grounded in two principles: the principle of obedience and the principle of contemplation. In this relation, obedience takes essentially the form of a permanent sacrifice of one's own will (Foucault 1993, p. 216). Contemplation, then, refers to contemplation of God. As Foucault notes, 'the obligation of the monk is continuously to turn his thought to that single point which is God [...]' (ibid.). The effect of contemplation, where the monk has to direct his thoughts towards God, is that he must take in hand not only his actions but also his thoughts in order to make certain that they really are constantly directed towards God (Foucault 1993, pp. 216-217). This requires not only constant examination of one's thoughts, but also deciphering their origin. After all, it is quite possible that the idea comes, not from God, but from Satan (Foucault 1993, p. 218). To find out whether an idea is rooted in bad sentiments, 'we have to decipher our thoughts as subjective data which have to be interpreted, which have to be scrutinized, in their roots and in their origins' (ibid.).

But how does one interpret one's thoughts? According to Cassian, ${ }^{8}$ to whom Foucault also refers, this is precisely by telling them to the master or your spiritual father. Verbalization of thoughts makes it possible to sort out bad thoughts from good ones. This is because one cannot easily talk about things that are inhabited by evil. But would it then be sufficient for the monk to verbalize his thoughts by himself? According to Foucault, no. The presence of someone is needed as that presence is the image of God. Verbalization of thoughts is a way of putting them before the eyes of God where they necessarily show their nature (Foucault 1993, pp. 219-220). From this it follows that verbalization itself has an interpretive function. Verbalization must go as deep as possible, because thoughts have obscure roots which need to be brought to light. As verbalization brings thoughts to light, it also leads to the movement of the human soul away from the reign of Satan and towards God. 'Since under the reign of Satan the human being was attached to himself, verbalization as a movement toward God is a renunciation of Satan, and a renunciation to oneself.' Therefore, verbalization is a form of self-sacrifice (Foucault 1993, p. 220).

In this peculiar way, a common root can be found for exomologesis and exagoreusis. As Foucault notes, they are in fact deeply and closely related (Foucault 1993, p. 221). Obligation to renounce oneself finds parallel in the martyrdom discussed in relation to exomologesis. According to Foucault:

the revelation of the truth about oneself cannot be dissociated from the obligation to renounce oneself. We have to sacrifice the self in order to discover the truth about ourself, and we have to discover the truth about ourself in order to sacrifice ourself. (Ibid.)

Therefore, there is no truth about the self without the sacrifice of the self (Foucault 1993, p. 222). This practice appears to become visible in Mr Beck's case: verbalization of his inner thoughts led, quite literally, to the sacrifice of his career. In his case, also the other aspect of these self-technologies is present: truth is not produced

\footnotetext{
8 John Cassian (c. AD 360 - c. 435) was a Christian monk and theologian.
} 
via coercion but inner motivation to speak out the deepest secrets of oneself. In the beginning of this article, two archetypes-the priest and the doctor-were introduced. Now what seems to be emerging is the idea of entanglement of these two characters. In case of Mr Beck, a priest and a doctor appear in himself. The requirement to examine and scrutinize one's thoughts includes an interpretive function as one has to keep up with the contemporaneous flow of thoughts in order to separate good thoughts from the bad ones.

However, as described, verbalization alone is not sufficient. Confession has to be made to someone and, in and through that act, the thoughts are brought to light. What was remotely present in the case of Smith and Grady, becomes more clearly visible with the case of Mr Beck. While the military organization, as it were, requires the confession, it also fosters a fundamental suspicion towards the individual, asking: is what Mr Beck is saying really the truth about himself? This suspicion is then channelled via the medical system when a statement from a psychiatrist is obtained. Also, this way the characters of the priest and the doctor make yet another appearance.

\section{The Court's Judgments}

On the basis of the preceding analysis, the answer to the first question of this article is that there is indeed a technique of confession at play in the cases. This technique operates, on the one hand, at the level of the military organization and, on the other hand, at the level of the individual. The military organization requires the confession and yet the confession does not form into truth without an outside interpreter representing the military. However, the way in which this technology operates does not merely take place within the military as such but can be understood as internalized practices of the individual as well. These are essentially the ways in which, based on the cases discussed here, the military organization produces knowledge about its subjects.

I will next move to answer the second question: what happens when this knowledge concerning the individual encounters the legal system? To answer this question, the Court's judgments in the two cases are analysed.

In both Beck, Copp and Bazeley and Smith and Grady the Court found a violation of Article 8 of the Convention. In Beck, Copp and Bazeley (para 53), the Court concluded that there was no difference between this case and the case of Smith and Grady. For this reason, it is sufficient to analyse the reasoning of the Court only in Smith and Grady.

As was explained above, the applicants complained that the investigations into their homosexuality and their subsequent discharge from the armed forces on the sole ground that they were homosexual, in pursuance of the Ministry of Defence's absolute policy against homosexuals in the British armed forces, constituted a violation of their right to respect for their private lives protected by Article 8 of the Convention (Smith and Grady v. The United Kingdom, para 69).

In such cases the Court's ruling always proceeds through certain standard questions. These include whether the issue falls within the scope of one of the substantive 
articles of the Convention, whether there was an interference with the right, whether the interference was based on law and whether the interference pursued a legitimate aim. Finally, the Court considers whether the interference was necessary in a democratic society in order to achieve the legitimate aim in question, whether it was proportionate to that aim and taking into account the margin of appreciation accorded to the States by the Convention. The answer to this fourth question is usually referred to as the 'democratic necessity test'. What this essentially means is that there must always be a proportionate relationship between the aims pursued by the interference and the Convention right at stake (Gerards 2013, p. 467).

In the case of Smith and Grady, the British Government accepted that there had been an interference with the applicants' right to private life; however, they were of the opinion that this interference was 'in accordance with the law' and had an aim which was legitimate and 'necessary in a democratic society' (Smith and Grady v. The United Kingdom, para 72).

The core argument of the British Government in support of the policy was that the presence of open or suspected homosexuals in the armed forces would have a substantial and negative effect on the morale and, consequently, on the fighting power and operational effectiveness of the armed forces (Smith and Grady v. The United Kingdom, para 95). Conversely, the applicants submitted that the interferences with their private lives, given the subject matter, nature and extent of the intrusions at issue, were serious and grave, and required particularly serious reasons by way of justification. According to the applicants, the subject matter of the interferences concerned the most intimate part of their private lives, which was made public by the Ministry of Defence's policy itself (Smith and Grady v. The United Kingdom, para 81). Although the applicants acknowledged the unique circumstances of military life, i.e. certain restrictions regarding the sphere of an individual's private life, the applicants also noted that 'the armed forces of a country exist to protect the liberties valued by a democratic society, and so the armed forces should not be allowed themselves to march over, and cause substantial damage to, such principles' (Smith and Grady v. The United Kingdom, para 83).

The Court held that both the discharges and the investigations done after the admissions of homosexuality violated the applicants' right to respect for private and family life. The Court found that while both were in accordance with the national law and had a legitimate aim, neither was 'necessary in a democratic society' as required by Article 8 . As the intrusions concerned one of the most intimate parts of an individual's private life, the Court noted that 'particularly serious reasons' are required to justify them (Smith and Grady v. The United Kingdom, para 89). In the context of armed forces, this meant that there must have been a 'real threat' to their operational effectiveness (ibid.).

The Court noted that the evidence provided by the British Government, on the basis of which the military supported its policy to exclude homosexuals, was solely based on negative attitudes towards homosexuals by current soldiers (Smith and Grady v. The United Kingdom, para 96-97). The Court found that this, especially when considered against the backdrop of the successes of integrating women and racial minorities into the military, was not 'convincing and weighty' evidence to support the exclusionary policy (Smith and Grady v. The United Kingdom, para 
102-105). Likewise, the continued investigations after the applicants had already confessed to being homosexuals was a violation of Article 8 as the government's rationale of seeking to detect false claims of homosexuality was not sufficiently convincing and weighty (Smith and Grady v. The United Kingdom, para 106-110).

\section{Polyvalent Law?}

It is often argued that Foucault failed to acknowledge the importance of law in modernity and that in his analyses he did not sufficiently consider the role of law (Golder and Fitzpatrick 2009, p. 23). This stance is generally referred to as the 'expulsion thesis' (see e.g. Hirst 1986; Hunt 1992; Munro 2001). At the core of the expulsion thesis is the identification of law as a pre-modern, negative and repressive, form of power. This form of power then became overtaken by a new form of power, namely disciplinary power (Golder and Fitzpatrick 2009, p. 24). This change would also mark a transition from the pre-modern to the modern, in which law and sovereignty became less important as sites of power (ibid.). As Bob Fine notes, according to this view, law was completely subordinated by disciplinary power (1984, p. 200). Law, which was considered essentially as a negative mode of power by Foucault, was then overtaken by more productive modes of power; modes, that rendered law as an instrument to their own operation (Golder and Fitzpatrick 2009, pp. 25-26).

However, other accounts have also been introduced, the most famous perhaps being the one by Ben Golder and Peter Fitzpatrick. They argue that, to the contrary, Foucault's law could not be subordinated by disciplinary or other forms of power as power in Foucault's register exists 'in a relational dynamic of mutual constitution with disciplinary power' (Golder and Fitzpatrick 2009, pp. 150-151). Golder and Fitzpatrick argue that Foucault's law is a vacuous concept, open to different kinds of inputs from other social systems and functions. It is precisely this openness that makes sure that law cannot be completely occupied by external powers. Although law can be made to serve other powers, it is this quality of being able to be subordinated in a given situation that prevents the law from being definitively encompassed by these other powers (Golder and Fitzpatrick 2009, pp. 152-153).

From these notions we move to discuss law's polyvalent nature. This type of approach would deal with law as an empty shell, in a sense (cf. Ewald 1988, p. 36). ${ }^{9}$ Because of this, law cannot be tied to any singular and determinate form (Golder and Fitzpatrick 2009, pp. 125-126). As Foucault himself writes in Nietzsche, Genealogy, History: 'rules are empty in themselves' (Foucault 2000b, p. 378). Rules can be occupied by powers external to them but it is indeed this vacuity due to which law cannot be contained by other powers. As Golder and Fitzpatrick note, 'the vacuity of Foucault's law is polyvalent vacuity, an insubordinate openness, for the "strategic reversibility", (Golder and Fitzpatrick 2009, p. 127). While some commentators have aimed to place law in contrast to disciplinary power, as restraining it (see

\footnotetext{
9 Ewald notes that 'it is a fact that there is no (positive) law without a law of law; no law without a principle, an instance of reflexion, whereby the law thinks about itself.'.
} 
e.g. Goldstein 1993), the idea of polyvalent law would rather acknowledge that law can operate as a form of resistance; however this is not because of some righteous essence of law but because of its capability to be harnessed for different strategic purposes. This way we might conclude that law can be instrumentalized for the purposes of, for example, disciplinary techniques but it can also be used by individuals for the articulation of rights.

However, is it really so that the 'rules are empty in themselves?' This takes us to the old discussion about the responsiveness and reflexivity of the law. The introductions to the thematic have been famously made by Philippe Nonet and Philip Selznick (2009 [1978]) as well as Gunther Teubner (1983). Responsivity of the law can be shortly described as the law's capability to consider and react to inputs from other social functions and regimes whereas reflexivity refers to the idea of law as 'a system for the coordination of action within and between semi-autonomous social subsystems' (Teubner 1983, p. 242). As Peer Zumbansen notes,

although the law was placed at a unique place from which it would constantly receive manifold communications, influences and pressures from different parts of society, its evolution depended on its ability to maintain this intricate relationship to its environment. Its self-reproduction depended on its constant exposure to the forces of society, while reconstructing these signals in its own language or code. (Zumbansen 2008, p. 792)

To my understanding, this would mean that the law is not completely subordinated by other social forces but rather retains a certain fundamental structure of its own. In the context of the two cases being addressed in this article, could we think that this fundamental structure is precisely the functioning of the human rights system? As presented by Kaarlo Tuori, human rights belong to deep structure of the legal system (2002, pp. 192-193). According to Tuori, 'the deep structure of modem law is defined by basic categories such as "legal subjectivity" and "subjective right" and by fundamental principles such as human rights as general normative ideas' (2002, p. 192). These categories construct the framework within which we can think in legal terms at the surface level of the law; the level where everyday legal actions take place.

Could there be a way to combine these approaches? Let us consider some of the features of these cases. First, both parties rely on previous cases, claiming that these are either analogous to the case at hand or different from it, meaning that the case at hand should be resolved either by following the previous cases or differently from the ones with a less desirable outcome. The Court will then decide which cases are relevant regarding the case at hand. This is an important part since due to these strategic choices of the parties the other one's interpretation of the case is often taken as the basis of the judgment. Second, the parties need to translate their problem into the legal grammar. In these cases this meant that, on the one hand, the applicants translated their sense of injustice into a question of whether there had been a violation of Article 8 of the Convention. This is essentially a question of an individual right. The British Government, on the other hand, relied on the legitimate aim of securing the functioning of the armed forces. These elements, the individual right 
and the legitimate aim, could be considered as belonging to the fundamental functioning logic of the human rights system established by the Convention.

Would this mean, then, that the polyvalence thesis is not an accurate description of these cases? The answer is not that straightforward. First of all, my interpretation of the polyvalence thesis is that the essential feature of it is indeed the strategic elements it brings to fore. By considering the praxis of the Court as consisting of strategic relationships, we can detect that both parties in the case have their own strategy in order to win the case. But is there a strategic element in the judgment as well? Some accounts would definitely argue so. For example, Paul Johnson notes that the applicants also appealed on Article 3, which prohibits degrading treatment or punishment. The Court then concluded that while the investigations were undoubtedly distressing and humiliating for the applicants, the treatment did not reach the minimum level of severity to bring it within the scope of Article 3 of the Convention (Smith and Grady v. The United Kingdom, 122). According to Johnson, this is precisely a manifestation of the tendency to treat issues of homosexuality as essentially private issues (2014, pp. 101 and 103-104). Indeed, the Court has been criticized for its supposedly moralistic judgments (Johnson 2014, p. 103; Moran 1998; see also Grigolo 2003).

However, the contending interpretation would be that while the functioning logic of the Court is not strategic in itself in this moment of history, it is nevertheless a product of historical power struggles. This would bring us back to the polyvalence theory. Also the fundamental operation of the legal system is a product of strategic moves: powers that operate in the society also shape the legal system, some faster and some slower. While law is not devoid of power or value-free, the values embedded in law as a result of strategic power-struggles can change over time.

This brings us the answer to the second question of this article, namely what happens when knowledge about sexuality obtained through the technique of confession encounters the legal system. First, we can see how both parties aim to use the law for their own purposes: the military to sustain its techniques of governing and the applicants to resist this power. Based on these cases, it would indeed seem that law does not that easily lend itself to attempts of occupation by other forms of power. Instead, it could be said that law present a certain kind of resistance to other forms of power. But is this resistance due to the successful strategic movements of the applicants or the functioning of the law as such? To conclude, I would argue that both these accounts can be true at the same time. Indeed, the strategic movements of the parties shape the judgment but at the same time there is a historically situated and contingent 'core' of the law which also guides what kind of claims can be posed before the Court in the first place. This is a two-way movement between what Tuori calls the surface level and deep structure of the law. As Tuori also notes, this is necessarily an analytical division. In practice, the levels and different functions of the law form an organic whole (2002, p. 192). Perhaps we could say that this whole is polyvalent by its nature. 


\section{Conclusions}

The purpose of this paper was to illustrate, first, how the military organization produces knowledge about its subjects and, second, what happens when this knowledge encounters the legal system. Let me now draw together some conclusions.

On the one hand, it seemed that the military organization demanded confession and it had indeed developed extensive technologies to produce that kind of information. This became visible in the case of Smith and Grady, where the confession was extended to all corners of the individual's sphere of life, from economic affairs to hobbies and sexual practices. On the other hand, the way in which these technologies operate does not merely take place within the system as such but can be understood as internalized practices of the individuals as well. An example of this was the case of Beck, where the applicant felt the moral obligation to confess his homosexuality although this was not required of him. What then ties these two cases together is what became especially visible in the case of Beck, from the way his confession was received. Indeed, there was a need to make sure that he was telling the truth. In both Smith and Grady and Beck, a fundamental suspicion regarding what these individuals had to say manifests itself. This takes us back to the priest and the doctor. Confession alone is not sufficient but an outside interpreter is needed for the confession to be seen as constituting the truth.

However, these archetypes do not appear in isolation but, as was observed in the case of Beck, they also intertwine. The interpreter-the doctor-is neither explicitly an outsider, but confession includes a kind of hermeneutic aspect which leads to a situation where individuals start to observe their own thoughts in order to decipher their meaning and origin. In this regard it also becomes visible how the technologies of knowledge production are not merely something external to the individual but also operate from within the subject.

What also seemed to be present in both of these cases was the way in which the representatives of the military organization were needed as the interpreters of the applicants' homosexuality. The military is, thus, the condition for the production of knowledge about the individual's inner world in that the system can, as it were, tell the truth about the individual-something that is unknown to the individual themselves. This operation of truth-production is necessarily also a manifestation of a power relationship, an exercise of power directed to the individual's sphere of privacy. This became visible when these issues were observed together with Article 8 of the Convention on the right to private and family life.

Then, what happened when this knowledge obtained for the purposes of the military came into contact with law? In this regard, we moved to discuss the judgment and the Court's reasoning as well as Foucauldian theories of law, namely the expulsion thesis and the polyvalence theory. However, saying that law would be completely occupied by e.g. disciplinary power seemed a bit of an exaggeration. Instead, both cases were decided in favour of the applicants: the Court balanced individual rights higher in the discussed cases in comparison to the societal aims that the British Government had chosen as its strategy. Foucauldian legal theories were then discussed in comparison with the old theories about the responsiveness 
and reflexivity of the law; the question being, are rules empty or is there some kind of a fundamental functioning logic or 'core' of the legal system, so to say. It was then concluded that it is precisely the strategic openness of the polyvalence theory that could be considered to reside in the 'core' of law. This feature would also be the one to resist occupation from other forms of power. Because law, by nature, can be mobilized for different strategic moves it can never be completely overtaken by other forms of power.

To sum, there is a technique of confession at play within the military organization, which operates on the one hand at the level of organization itself and on the other hand, at the level of the subject. The military organization requires the confession and this input from the system causes the individuals to confess, seemingly out of their own initiative but when we take a closer look, it rather appears that this is precisely the technique of confession at work in the inner world of the subject. When this knowledge about the individual encounters the legal system, what appears to happen is that it runs into certain trouble. However, this is not necessarily because law is 'good' and disciplinary power is 'bad' but is rather caused by the fundamental logic of law at play. This is the 'strategic reversibility' of the law.

It is clear that this article only provides a brief outlook into these matters. One purpose of this article can indeed be described as opening more questions rather than providing definitive answers. Some issues that will be left for further analysis are, for example, whether these results are generalisable? Does confession operate only in the military context or can we detect ways in which confession operates also in other societal contexts? How does law function and should we understand its operation as a vacuous concept, empty shell, just sitting there and waiting to be possessed by external powers? Or are there some fundamental values beneath the surface of the legal system, guiding its operation and this way aiding to resist these external powers?

Acknowledgements I am grateful to the two anonymous reviewers for Law and Critique whose comments greatly improved the article. I would also like to thank Samuli Hurri and Julian Reid for their unwavering support and constructive comments throughout the process; Joonas Vola for commenting on the early drafts; and Tomi Tuominen for his comments and assistance in several phases of preparing this article.

Funding Open access funding provided by University of Lapland.

Open Access This article is licensed under a Creative Commons Attribution 4.0 International License, which permits use, sharing, adaptation, distribution and reproduction in any medium or format, as long as you give appropriate credit to the original author(s) and the source, provide a link to the Creative Commons licence, and indicate if changes were made. The images or other third party material in this article are included in the article's Creative Commons licence, unless indicated otherwise in a credit line to the material. If material is not included in the article's Creative Commons licence and your intended use is not permitted by statutory regulation or exceeds the permitted use, you will need to obtain permission directly from the copyright holder. To view a copy of this licence, visit http://creativecommons.org/licen ses/by/4.0/. 


\section{References}

Behrent, Michael C. 2013. Foucault and technology. History and Technology 29 (1): 54-104.

Blasius, Mark. 1993. Introductory note. In About the beginning of the hermeneutics of the self. Two lectures at Dartmouth, Michel Foucault. Political Theory 21 (2): 198-227.

Coe, Cynthia D. 2016. Review: About the beginning of the hermeneutics of the self: Lectures at Dartmouth College. Notre Dame: Philosophical Reviews. https://ndpr.nd.edu/news/about-the-beginningof-the-hermeneutics-of-the-self-lectures-at-dartmouth-college/. Accessed 4 July 2020

Davidson, Arnold I. 2003. Introduction. In Abnormal Lectures at the College de France 1974-1975, Michel Foucault. London: Verso.

Elden, Stuart. 2005. The problem of confession: The productive failure of Foucault's history of sexuality. Journal for Cultural Research 9 (1): 23-41.

Ewald, Francois. 1988. The law of law. In Autopoietic law: A new approach to law and society, ed. Gunther Teubner. Berlin: Walter de Gruyter.

Fine, Bob. 1984. Democracy and the rule of law: Liberal ideas and Marxist critiques. London: Pluto Press.

Foucault, Michel. 1976. The will to knowledge: The history of sexuality, vol. 1. London: Penguin Books.

Foucault, Michel. 1980. Introduction. In Herculine Barbin: Being the recently discovered memoirs of a nineteenth-century French hermaphrodite. New York: Pantheon Books.

Foucault, Michel. 1990. The use of pleasure. New York: Vintage Books.

Foucault, Michel. 1993. About the beginning of the hermeneutics of the self: Two lectures at Dartmouth. Political Theory 21 (2): 198-227.

Foucault, Michel. 1995. Discipline and punish: The birth of the prison. New York: Vintage Books.

Foucault, Michel. 2000a. Truth and juridical forms. In Michel Foucault: Power. Essential works of Foucault 1954-1984, Vol. 3, ed. James D. Faubion, 1-89. New York: The New Press.

Foucault Michel, 2000b. Nietzsche, Genealogy, History. In Michel Foucault: Aesthetics, method and epistemology. Essential works of Foucault 1954-1984, Vol. 2, ed. James D. Faubion, 369-391. New York: The New Press.

Foucault, Michel. 2005. The hermeneutics of the subject: Lectures at the College de France 1981-1982. New York: St Martin's Press.

Foucault, Michel. 2014a. Wrong-doing, truth-telling. The function of avowal in justice. Chicago: University of Chicago Press.

Foucault, Michel. 2014b. On the government of the living; Lectures at the Collège de France 1979-1980. New York: Palgrave MacMillan.

Foucault, Michel. 2017. Subjectivity and truth: Lectures at the Collège de France 1980-1981. Basingstoke \& New York: Palgrave MacMillan.

Freud, Sigmund. 1952 [1910]. Five lectures on psychoanalysis. New York: WW Norton.

Gerards, Janneke. 2013. How to improve the necessity test of the European Court of Human Rights. International Journal of Constitutional Law 11 (2): 466-490.

Golder, Ben, and Peter Fitzpatrick. 2009. Foucault's law. Oxon, New York: Routledge.

Goldstein, Jan. 1993. Framing discipline with law: Problems and promises of the liberal state. American Historical Review 98 (2): 364-375.

Grigolo, Michele. 2003. Sexualities and the ECHR: Introducing the universal sexual legal subject. European Journal of International Law 14 (5): 1023-1044.

Hirst, Paul Q. 1986. Law, socialism and democracy. London, Boston: Allen \& Unwin.

Home Office. 1957. Report of the Committee on Homosexual Offences and Prostitution.

Hunt, Alan. 1992. Foucault's expulsion of law: Toward a retrieval. Law and Social Inquiry 17 (1): 1-38.

Johnson, Paul. 2014. Homosexuality and the European Court of Human Rights. Oxon, New York: Routledge.

Mandziuk, Roseann M. 2001. Confessional discourse and modern desires: Power and please in true story magazine. Critical Studies in Media Communication 18 (2): 174-193.

Matabane, Palesa Flory. 2017. I confess therefore I am: How can online confession be used in a social media cyber performance. University of Pretoria.

Larry, May, and Bohman James. 1997. Sexuality, masculinity, and confession. Hypatia 12 (1): 138-154.

Moran, Leslie J. 1998. Laskey v. the United Kingdom: Learning the limits of privacy. The Modern Law Review 61 (1): 77-84. 
Munro, Vanessa E. 2001. Legal feminism and Foucault-A critique of the expulsion of law. Journal of Law and Society 28 (4): 546-567.

Nonet, Philippe, and Philip Selznick. 2009. Toward responsive law: Law and society in transition. New Brunswick, London: Transaction Publishers.

Peters, Michael. 2003. Writing the self: Wittgenstein, confession and pedagogy. Journal of the Philosophy of Education 34 (2): 353-368.

Posel, Deborah. 2008. History as confession: The case of the South African Truth and Reconciliation Commission. Public Culture 20 (1): 119-141.

Rose, Nikolas. 1990. Governing the soul: The shaping of the private self. London: Routledge.

Salter, Mark B. 2007. Governmentalities of an airport: Heterotopia and confession. International Political Sociology 1: 49-66.

Taylor, Chloë. 2009. The culture of confession from Augustine to Foucault: A genealogy of the 'confessing animal.' New York: Routledge.

Tell, Dave. 2010. Rhetoric and power: An inquiry into Foucault's critique of confession. Philosophy and Rhetoric 43 (2): 95-117.

Teubner, Gunther. 1983. Substantive and reflexive elements in modern law. Law and Society Review 17: 239-285.

Tuori, Kaarlo. 2002. Critical legal positivism. London, New York: Routledge.

Zumbansen, Peer. 2008. Law after the welfare state: Formalism, functionalism, and the ironic turn of reflexive law. The American Journal of Comparative Law 56 (3): 769-808.

\section{Cases: European Court of Human Rights}

Case of A.P., Garcon and Nicot v. France. (Applications nos. 79885/12, 52471/13 and 52596/13), 6.4.2017.

Case of Beck, Copp and Bazeley v. The United Kingdom (Applications nos. 48535/99, 48536/99 and 48537/99), 22.10.2002.

Case of Smith and Grady v. The United Kingdom (Applications nos. 33985/96 and 33986/96), 27.9.1999.

\section{Court of Justice of the European Union}

C-473/16 F v. Bevándorlási és Állampolgársági Hivatal, ECLI:EU:C:2018:36.

Publisher's Note Springer Nature remains neutral with regard to jurisdictional claims in published maps and institutional affiliations. 